Caligrama, Belo Horizonte, v. 24, n. 1, p. 47-64, 2019

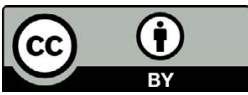

\title{
Pós-modernidade e pós-colonialidade na literatura latino-americana: o trágico na Crônica de uma morte anunciada, de Gabriel García Márquez
}

\section{Postmodernity and Post-Coloniality in Latin American Literature: The Tragic in the "Chronicle of a Death Foretold" by Gabriel García Márquez.}

Fatima Sabrina Rosa

Universidade do Vale do Rio dos Sinos (Unisinos), São Leopoldo, Rio Grande do Sul / Brasil

sabrinna.rosa@hotmail.com

Barbara Rosa

Secretaria de Educação do Estado do Rio Grande do Sul (SEDUC-RS), Porto Alegre, Rio Grande do Sul / Brasil

barbarajucele@hotmail.com

Resumo: Este ensaio tem por objetivo utilizar perspectivas discutidas em torno das teorias pós-modernas e pós-coloniais como aporte para estabelecer aproximações com a literatura latino-americana, especificamente, com a obra Crônica de uma morte anunciada, do colombiano Gabriel García Márquez. Essa proposta de aproximação surge da impressão causada pela obra no leitor, denotando traços do que poderia ser visto como uma perspectiva pós-moderna e pós-colonial sobre a história e sobre a própria escrita literária. Esses caminhos da questão "pós" podem ser percebidos em uma sensibilidade trágica, que alinha o texto aos debates pós-modernos, bem como na forma como o autor hibridiza a narrativa ao colocar na mesma "persona", narrador, personagem e autor. As chamadas "histórias menores", isto é, discussões acerca de temas importantes da crítica pós-colonial também estão presentes, em referências tangenciais à raça, territorialidade e gênero. Além dessas circunscrições mais visíveis sobre o "pós" na estrutura da crônica, este texto é uma tentativa de decodificar alguns 
símbolos utilizados pelo autor para ressignificar e deslocar certos pontos fixos da ficção e da história latino-americana.

Palavras-chave: literatura latino-americana; trágico; pós-modernidade e póscolonialidade.

Abstract: This essay aims to use perspectives discussed on postmodern and postcolonial theories as a contribution to establish approximations with the Latin American literature, specifically with the Chronicle of a Death Foretold by the Colombian Gabriel García Márquez. This proposal of approximation arises from the impression that the García Márquez' work provokes in the reader, denoting traces of what could be seen as a postmodern and postcolonial perspective on history and on literary writing itself. These paths of the "post" theory can be perceived in a tragic sensibility, which aligns the text to postmodern debates, as well as in the way the author hybridizes the narrative by placing the narrator, character and author in the same person. Also present in the book are the so-called "minor stories," that is, discussions about the central postcolonial critique matters, such as issues about race, territoriality, and gender. In addition to these more visible circumscriptions about the "post" in the structure of the Chronicle, this text is an attempt to decode some symbols used by the author to resignify and dislocate certain fixed points of Latin American fiction and history.

Keywords: Latin American literature; tragic; post-modernity and post-coloniality.

\section{Introdução}

Na Crônica de uma morte anunciada, de 1981, García Márquez reconstrói um cenário já conhecido em suas outras obras. Num povoado na costa do Caribe, próximo a Curaçao e Manaure, acontece o suplício de Santiago Nasar. O personagem assassinado era filho de Ibrahim Nasar, um árabe. Tinha recém completado 21 anos, era belo e rico. Morava com sua mãe, Plácida Linero, numa grande casa perto do porto, onde também viviam como serviçais duas mulheres indígenas, Victória Guzmán e sua filha Divina Flor, que entrava na adolescência. Na noite anterior à sua morte, Santiago esteve com alguns amigos (entre eles o narrador) e grande parte do povoado na festa de casamento de Ângela Vicário e Bayardo San Román. Na noite de núpcias, a noiva, que havia se casado contra a sua vontade, foi devolvida à família pelo fato de não ser virgem. Quando interpelada sobre quem a teria seduzido, não hesitou em lançar o nome de Santiago Nasar que, em consequência de tal acusação, foi jurado de morte pelos irmãos gêmeos Pablo e Pedro 
Vicário. Santiago Nasar foi dormir às 4 h da manhã e às 5 h $30 \mathrm{~min}$. já estava de pé novamente para ver o bispo que passaria pelo porto. Durante esse tempo, os irmãos o estiveram esperando para matá-lo perto de sua casa e tentaram, de todo modo, anunciar a sentença para que alguém os impedisse de realizar seu dever de honra. Várias pessoas pensaram em avisá-lo, mas uma sucessão de fatos fez com que se tornasse impossível aos irmãos evitar a consumação do crime. Santiago foi morto a facadas na porta de sua casa, a qual estava fechada porque sua mãe achava que ele já havia entrado e estava a salvo.

O autor, que também é personagem e narrador, não tece o texto na forma linear como foi descrito acima, mas organiza um caleidoscópio com fragmentos do depoimento de várias pessoas do povoado, deixando ao leitor um espaço para a organização e montagem dos fatos que culminaram no assassinato.

De acordo com Herscovitz (2004), esta crônica é o resultado da combinação da atuação jornalística com a produção literária de Gabriel García Márquez. A história narrada é a adaptação de um crime que de fato aconteceu em Sucre, cidade onde morou a família do autor. Conforme Martin (2010, p. 495):

[...] um jovem chamado Miguel Palencia havia recebido um bilhete dizendo que a nova esposa, Margarita Chica Salas, não era mais virgem, e por isso ele a devolveria, em desgraça, à família. No dia 22, os irmãos de Margarita Víctor Manuel e José Joaquín Chica Salas assassinaram seu ex-namorado Cayetano Gentile Chimento, na praça principal [...] O assassinato fora horripilante: Gentile fora quase cortado em pedaços.

Como as famílias eram íntimas, a mãe aconselhou Márquez a não escrever enquanto a maioria dos envolvidos estivessem vivos. Passados trinta anos do ocorrido, o autor reconfigura a história, conferindo-lhe uma tonalidade das tragédias gregas e constrói uma narrativa dramática, dinâmica e complexa que, ao entrelaçar pessoas reais com personagens, situações reais com imaginárias, adquire também uma dimensão autobiográfica. O narrador é também o próprio autor que, ao longo do texto vai se revelando através das referências feitas às pessoas da família, entre estas, os irmãos Margot - Luis Henrique e Jaime -, a mãe de Márquez e Mercedes, sua esposa. 
Crônica de uma morte anunciada é o primeiro livro a ser escrito depois de um jejum de sete anos em que o autor esteve envolvido com o ativismo político e apresenta uma imensa mudança no ponto de vista literário, uma vez que parte da culpa pelos infortúnios sofridos já não é atribuída com tanta força ao sistema capitalista e aos governos ditatoriais, mas "sobre um sistema social muito mais antigo e profundo, bastante influenciado pela igreja católica" (MARTIN, 2010, p. 495). Mesmo não tendo presenciado o crime, o autor o soube pela irmã que tinha relação estreita com a família do jovem assassinado, pois era afilhada de sua mãe. Trinta anos depois do ocorrido, García Márquez resolveu recontar a história renomeando os personagens e reconfigurando a narrativa.

\section{Pós-modernidade, pós-colonialidade e a literatura de Gabriel García Márquez}

A ideia de um "pós" não pode ser definida a priori, uma vez que o termo não existe em si mesmo, apenas em relação àquilo que nomeia. (GADEA, 2013) O que se pode dizer sem conceituar esse prefixo é que designa não uma posterioridade ou uma crise com a qual frequentemente é relacionado, mas uma sensibilidade. Em relação à modernidade, o "pós" pode designar uma radicalização ou um sentido de extenuação de seus preceitos, como a racionalidade. O "pós" é uma visão que supera as dualizações propagadas pelo modelo cartesiano e iluminista de pensamento, não compreende o mundo como dividido entre racional e irracional, civilizado e bárbaro, feio e bonito (LYOTARD, 2004), (TORO, 2013). Sendo trágico, isto é irresolvível, o "pós" não rejeita contradição em nome de uma resposta única. Quanto à colonialidade, a sensibilidade "pós" parte de uma fuga às antinomias que opuseram países colonialistas e colonizados e suas características sempre destacáveis nos primeiros e sempre símbolos de atraso no segundo.

Pertencentes, num primeiro momento, à área da teoria literária, os debates em torno da pós-colonialidade se dedicaram a analisar e criticar a forma como as narrativas eurocentradas produziram uma determinada verdade sobre os sujeitos a quem se referem, posicionando o "outro" da modernidade como uma segunda classe e perpetuando, desse modo, visões coloniais sobre as relações entre Ocidente e Oriente tais como analisam Bhabha (2013), Said (2007) e Spivak (2010), bem como sobre as relações entre Europa e América e colonialidades internas ao 
continente analisadas por autores como Castro-Gómez (2005a; 2005b), e Toro (2007).

Dentro da gama de sensibilidades que buscam desnudar as dominações simbólicas presentes nas narrativas coloniais, o livro Orientalismo de Said (2007), mostra-se como o difusor da perspectiva pós-colonial, ao analisar de que forma o binarismo, que apresenta o Ocidente e o Oriente como dois modelos opostos de civilização, foi uma construção em que os ocidentais se permitiram uma dupla tarefa: a de se auto representar como padrão ideal de sociedade e a de definir o que seria o seu oposto, adaptando e produzindo uma série de relatos sobre o que seria o Oriente. A crítica de Said se baseia na premissa foucaultiana de que o conhecimento tende a referendar os discursos produzidos anteriormente, reproduzindo uma espiral de estereótipos e representações binárias que reforçam dominações históricas. Nesse sentido, o Orientalismo, mais do que marcar uma fronteira geográfica, situa uma fronteira cultural produzida pelos diversos discursos ocidentais sobre o Oriente que se impuseram como "regime de verdade" sobre esse lugar.

Herdeira e ao mesmo tempo a outra face da pós-modernidade, a pós-colonialidade revê a separação centro-periferia, feminino-masculino, desenvolvido-subdesenvolvido e busca a perspectiva sobre um "terceiro espaço" de fala (BHABHA, 2013) ou um espaço intersticial, no qual a resposta é impermanente, num constante vir a ser, que tende a romper com certa posição epistemológica privilegiada e conferir voz aos sujeitos silenciados por certa violência epistemológica, como as mulheres. Tal sensibilidade incide sobre a produção literária revelando uma nova concepção de representação das relações centro-periferia, bem como das outras dualidades que engendra (relacionadas a classe, raça e gênero) conferindo-lhe um caráter de denúncia das formas de violência e dominação, ao mesmo tempo que busca o rompimento da visão hierárquica imposta pelo pensamento colonial.

Para Toro e Ceballos (2007), Gabriel García Márquez faz parte de uma geração de autores expoentes da Literatura Latino-Americana ${ }^{2}$ que

\footnotetext{
${ }^{1}$ Termo emprestado por Bhabha de Frederick Jameson, o terceiro espaço ou espaço intersticial seria o lugar em que as identidades poderiam se forjar sem a dependência das temporalidades estabelecidas pelo discurso ocidental moderno.

${ }^{2}$ Assim como Mario Vargas Llosa, Jorge L. Borges, Carlos Fuentes, Júlio Cortázar e João Ubaldo Ribeiro.
} 
se libertaram do compromisso de produzir os tipos regionais e nacionais de cada país que o século anterior viu emergir em função de um dever pós-independentista. Tais autores também não fizeram parte da geração "antropofágica" que buscou imprimir o estilo modernista à literatura latino-americana adaptando traços europeus a um desenho específico local. Antes, estiveram na contramão de tais movimentos debochando da modernidade, seguindo e, ao mesmo tempo, pervertendo os padrões como o fez Borges.

Ao longo do século XX, a literatura passa por reconfigurações provocadas por uma série de debates que se localizam dentro e fora dos cânones europeus. Uma reconfiguração importante trata-se do chamado giro pós-moderno que influencia a literatura já na primeira metade do século XX, sendo visível nas obras de Borges, entre outros (TORO, 2007). Na segunda metade, os decorrentes debates sobre a pós-colonialidade, são influenciados tanto pelo giro pós-moderno quanto por outros movimentos como os estudos feministas e de subalternidade, os quais estabelecem uma crítica contundente ao positivismo, promovendo a flexibilização sobre os regimes de verdade, o que é considerado como real e a ideia de pluralismo como horizonte de compreensão dos fatos.

\section{Crítica pós-colonial e outros diálogos na crônica}

A contribuição fundamental de García Márquez é estabelecer a literatura como produção histórica de alteridades, logo, mais do que produzir outro olhar sobre a história oficial, o autor nos leva à compreensão de que toda história é também ficção, uma construção coletiva.

Ao se referir à nova novela histórica latino-americana, Toro e Ceballos (2007) observam que a reescrita da história oficial pela literatura pode ser percebida como uma forma de estabelecer paralelos mais reconhecíveis para a história dos povos da periferia.

La deslimitación de las fuentes" y una "ampliación y enriquecimiento de los materiales que sirven de punto de arranque para la interpretación"; "el principio de la 'altaridad', del 'escribir entre medio', 'de una escritura de la diferancia' se establecen como principio de construcción como alternativa a una discursividad histórica teleológica, unilateral, causal y cronológica". (TORO; CEBALLOS, 2007, p. 14) 
Pode-se ver a descrição da chegada do navio com o bispo como a chegada de algum ideal apolíneo para a América, como a racionalidade ou a civilização, essa "deidade" que apenas passa, mas nunca se estabelece no continente e que, por sua impermanência, resultamos inferiorizados. As pessoas se preparam para o evento, mas o navio não atraca, apenas passa ao largo do porto, onde as pessoas assistem ao bispo fazendo um sinal da cruz ao longe e a imagem de solidão e abandono se faz materializada em mais uma manhã letárgica construída pelo autor. "Foi uma ilusão fugaz: o bispo começou a fazer o sinal-da-cruz no ar diante da multidão no molhe, e continuou a fazê-lo de costas, sem malícia nem inspiração, até que o navio se perdeu de vista e só restou o alvoroço dos galos" (GARCÍA MÁRQUEZ, 2006, p.29). A mãe de Santiago adverte que não vale à pena ir vê-lo porque ele não gosta do povoado. Outro dado importante para compreender o sentido de algo divino e legítimo é sua oposição dionisíaca. A oposição ao bispo é justamente o Dr. Dionísio Iguarán, médico que viajou imediatamente após o casamento para não ver o bispo. Além disso, mostra desprezo pela Igreja quando, ao ver a autópsia mal realizada pelo Padre em Santiago, exclamou: "Tinha que ser padre pra ser tão burro" (GARCÍA MÁRQUEZ, 2006, 112). A relação da Igreja com um ideal civilizador europeu fica clara na forma como o padre atribui "anormalidades" a certos órgãos de Santiago, baseando as características de seu corpo ao dos europeus, sem nenhuma ressalva: "A massa encefálica pesava sessenta gramas mais que a de um inglês normal" (GARCÍA MÁRQUEZ, 2006, p. 113). Dionísio é quem se interpõe à análise e aos comentários do padre na autópsia como sendo impróprios porque são baseados na anatomia dos europeus e, logo, representativos daquilo que os latino-americanos deveriam ser: "Não houve maneira de fazê-lo entender nunca que o homem do trópico tem o fígado maior que o dos galegos" (GARCÍA MÁRQUEZ, 2006, 113).

Na crônica, pode-se ver certa dualidade, não como a constituição de pares antinômicos, mas como formas ambivalentes de leitura do mundo e dos fatos. Um desses exemplos é sobre os irmãos que cometem o assassinato. Transformados nos gêmeos Pedro e Paulo, García Márquez atribui aos irmãos características que se alternam, como se representasse neles duas faces da identidade de um mesmo sujeito, como um sujeito hifenizado ou hibridizado. Ora um dos irmãos estava mais propenso a matar Santiago, levado pelo dever de honra, ora este irmão cedia, mas o outro via-se obrigado a encorajá-lo a seguir com a reparação da 
família. A noção de ambivalência, cara às abordagens pós-modernas, está presente na ação dos Vicário e nas crenças das pessoas do povoado, muito representativas do imaginário latino-americano. A religiosidade, em alguns momentos, está ligada à cosmologia indígena: Plácida Linero "tinha ervas medicinais nas frontes para a eterna dor de cabeça que o filho lhe deixou na última vez que passou pelo quarto" (GARCÍA MÁRQUEZ, 2006, p. 13-14); em outros, as superstições também se fazem presentes como na interpretação dos sonhos feita pela mãe de Santiago que deveria ser realizada, ainda em jejum, para ter validade. Acrescenta-se a isso a crença católica e a superposição de racionalidades (de medicina e religiosidade) vistas no padre e no médico da região, um misto de racionalidade científica e características dionisíacas que também aponta para a noção de hibridez, fundamental nos debates sobre pós-modernidade e pós-colonialidade.

Também se pode estabelecer associação entre as personagens e a colonialidade ao observar a relação entre Santiago e a jovem indígena, Divina Flor. Como Almeida (2007) coloca, a figura da mulher indígena já foi, por várias vezes, representativa da América na literatura, como no caso de Iracema, de José de Alencar, em que a palavra é um anagrama do nome do continente. Santiago, sendo o filho rico de um árabe, pode ser visto como o estrangeiro que toma a posição de conquista sobre a mulher local. "Nesse contexto, em um movimento metonímico, possuir a mulher nativa equivaleria a possuir a nova terra recém-revelada aos europeus" (ALMEIDA, 2007, p 462). Esse imaginário colonial, na obra de José de Alencar, leva à morte da personagem indígena, mas, no caso de García Márquez, essa relação sofre um revés pós-colonial: Santiago não chega a possuir Divina Flor e ainda é morto de forma brutal, logo depois de desejar a menina na cena da cozinha e ver a mãe da jovem ameaçá-lo com uma faca suja do sangue dos coelhos: "Solte-a branco - ordenou-lhe seriamente - dessa água não beberá enquanto eu for viva" (GARCÍA MÁRQUEZ, 2006, p. 18). Nesse sentido, pode-se ver a punição de Santiago como um ajuste de contas sobre injustiças anteriores a seu nascimento. Note-se que mesmo sendo árabe, na frase é identificado como "branco".

Outra influência tanto da pós-modernidade quanto da póscolonialidade é o debate de gênero que se apresenta com fundamental importância na obra de García Márquez. Na crônica, as vozes femininas são em maior número que as masculinas e aquela que apresenta mais 
coerência está centrada na figura que é a mãe do narrador e, de certa forma, do autor também. Na trama, ela aparece como parente de Ângela e como madrinha de Santiago Nasar, Luíza Santiaga (o nome de Santiago, aliás, é em função dela: Santiaga - Santiago). Vale observar que Luíza Santiaga é o nome da mãe de García Márquez. Ela parece personificar uma consciência feminina que analisa parte das relações de dominação envolvidas na trama e quem também empresta ao narrador a capacidade de compreender elementos destas relações. Na primeira parte do texto em que aparece, lança uma frase sobre as três filhas de Pura Vicário que condensa as expectativas sobre oposições de gênero no pequeno povoado. Diz que os homens que as desposassem haviam de ser felizes porque elas nasceram para sofrer. Nesse sentido, nota-se que a instituição do casamento era um mal menor perto da solidão, mas havia de impor sempre o paradoxo de que, para que os homens fossem felizes, as mulheres deveriam ser resignadas.

Clotilde Armenta, a dona do armazém onde os Vicário esperaram para matar Santiago, também representa uma consciência feminina importante. Clotilde foi a única que tentou de fato impedir o crime, mandando pessoas avisarem a vítima e o delegado e chegando a segurar um dos irmãos quando estes se encaminhavam para o lado de Santiago. "Nesse dia compreendi [...] como nós mulheres estamos sozinhas no mundo" (GARCIA MÁRQUEZ, 2006, p. 94). Entendia que era necessário que alguém impedisse os irmãos de vingarem a honra de Ângela, mas ninguém deu ouvidos a ela e só compreenderam o fardo moral que carregavam os gêmeos quando o crime já estava consumado.

Clotilde e Luísa Santiaga são responsáveis por compreender e relatar a estrutura das relações de gênero que perfazia o modo como as pessoas viam o casamento e a educação dos filhos, utilizando como exemplo primordial a família de Ângela Vicário: "Puríssima del Carmen, a mãe, tinha sido professora primária até que casou para sempre [...] os irmãos foram criados para serem homens. Elas tinham sido educadas para casar" (GARCÍA MÁRQUEZ, 2006, p. 47). Essa fixidez das relações e expectativas sobre cada gênero não permitiria que o crime ficasse sem uma represália pelos Vicário.

Quanto à Ângela, ela seria quem se distingue da família, mostrando sua diferença e capacidade para o rompimento de tais relações de subserviência desde o nascimento. "Minha mãe dizia que nascera como as grandes rainhas da história, com o cordão umbilical enrolado 
no pescoço" (GARCÍA MÁRQUEZ, 2006, p.49), embora aparentasse pobreza de espírito até pouco depois do crime, quando passa a ser narrada como dotada de certo empoderamento. "Ângela Vicário não esqueceu nunca o horror da noite em que seus pais e suas irmãs mais velhas com seus maridos, reunidos na sala da casa, impuseram-lhe a obrigação de se casar com um homem que mal tinha visto" (GARCÍA MÁRQUEZ, 2006, p. 52). Os pais alegavam que a pobreza da família impedia que Ângela desperdiçasse o pretendente, visto como um prêmio. Por essa obrigação de casar-se, ela veria o pretendente com certa displicência até o momento em que é devolvida.

Ao recusar-se a seguir com a farsa de sua virgindade, Ângela rompe a relação silenciosa de subserviência, mas, ao vestir-se como uma noiva virgem, mostra-se indiferente ao significado desses símbolos para a religião e não se assusta com a possibilidade de ser castigada por profaná-los.

O fato de que Ângela Vicário se atrevesse a pôr véu e as flores de laranjeira sem ser virgem havia de ser interpretado como uma profanação dos símbolos de pureza [...] Só minha mãe considerou um ato de coragem o fato de ela haver jogado com cartas marcadas até as últimas consequências. (GARCÍA MÁRQUEZ, 2006, p. 20).

Mais uma vez é da "mãe do autor" a voz capaz de compreender a difícil posição de sujeito em que Ângela se encontrava, vendo sua mentira como autopreservação. Essa compreensão é perpassada ao leitor pela forma com que a história é narrada sem imputar diretamente uma culpa à mulher sobre o crime cometido. Se Ângela não queria o casamento porque não tinha escolha individual, no momento em que decide deixar-se descobrir por Bayardo San Román pode estar punindo o então marido pelo seu destino e por ter escolhido conquistar a todos do povoado, mas não à Ângela e ter decidido sobre casar-se com ela à revelia de sua vontade.

Apenas quando sai do povoado e vai para uma pequena casa em um lugar tão inóspito como se estivesse em penitência, é que Ângela se encontra com sua solidão e, logo, sua liberdade: "Pela primeira vez dona de seu destino, Ângela Vicário descobriu então que o ódio e o amor são paixões recíprocas" (GARCÍA MÁRQUEZ, 2006, p. 137). Então, se vê imbuída de um amor que não sentia reencontrando, quase 20 anos depois, Bayardo San Román. Em relação ao dialogismo com a tragédia 
grega realizado pelo autor, pode-se inferir que a posição emancipatória de Ângela esteja associada à figura da heroína trágica de Sófocles, Antígona. ${ }^{3}$

Outro aspecto de rompimento com as relações de subalternidade é retratado no interior da casa dos Nasar. A morte de Santiago limita a continuidade de uma relação de subalternidade entre os Nasar e as trabalhadoras domésticas de sua casa. Assim como a mãe de Divina Flor foi constantemente abusada por Ibrahim, pai de Santiago, ela já percebia que este vinha estabelecendo a mesma relação com sua filha adolescente. Passaria para a geração próxima o legado de dominação, tanto de uma etnia sobre outra, como também uma perversa relação de classe e gênero, que coloca a sexualidade da mulher mestiça e indígena como parte do contrato de trabalho como serviçal doméstica. Essa questão fica clara na fala de Divina Flor sobre o dia da morte de Santiago: "Me agarrou a buceta todinha $[. .$.$] era o que fazia sempre quando me encontrava sozinha pelos$ cantos da casa" (GARCÍA MÁRQUEZ, 2006, p. 23). No entanto, com a morte de Santiago, essa continuidade é interrompida para o alívio da mãe de Divina Flor. Em uma passagem do livro o autor revela que, mesmo que a possibilidade da morte de Nasar fosse um tanto negligenciada, a única pessoa que desejava essa morte era Victória Guzmán. A cena em que as duas indígenas aparecem destripando um coelho, à semelhança de como Nasar foi morto, é representativa desse antagonismo. Victória Guzmán "não pode disfarçar um brilho de espanto ao recordar o horror de Santiago Nasar quando ela arrancou de uma vez as entranhas de um coelho e atirou aos cães as vísceras palpitantes". Essa cena também parece ser uma metáfora da relação entre a pureza do coelho que é destrinchado enquanto cães, símbolos de sexualidade, aguardam ofegantes sua parte na presa.

Em seu livro Macondoamérica, Rodrigues (1993) faz uma análise detalhada sobre como García Márquez centra sua narrativa na matrifocalidade e na denúncia do machismo presente na cultura sul americana. A autora revela que o machismo mascara, através da dominação masculina, a dependência do homem em relação à mulher a qual é perpetuada, principalmente, pelo culto à figura da mãe. Entre os

\footnotetext{
${ }^{3}$ Antígona é exaltada como aquela que se revolta com o poder do Estado, simbolizado por Creonte; aquela que se insurge contra as convenções e as regras, em nome das leis, não-escritas, as de sua consciência e de seu amor, é a jovem emancipada que deixa no jazigo familiar o despojo da inocente, esmagada pelos hábitos e pelas repressões sociais (CHAVALIER; GHEERBRANT, 2002, p. 64).
} 
motivos que levariam à construção de uma sociedade matrifocal estão "a condição migrante de muitos trabalhadores; o resíduo do padrão africano da família polígama, em que a mãe era o centro da família e o pai uma quase ausência; o modelo de união extraconjugal nas classes altas, que favorece a existência de filhos em torno de uma mãe e a ausência do pai” (RODRIGUES, 1993, p.111). A autora também cita o estudioso Gordow Lewis que sugere que "o catolicismo europeu teria forjado o ideal de autoritarismo masculino" (RODRIGUES, 1993, p.111) e este autoritarismo, em casos extremos, teria submetido a mulher a uma situação de "quase escravidão". É em contraposição a este padrão histórico cultural injusto no qual a mulher deve permanecer passiva e resignada que García Márquez apresenta Ângela rompendo corajosamente seu pacto de resiliência e que Divina Flor se liberta da possibilidade de exploração sexual devido a fatalidade violenta da morte de Nasar.

\section{Tragédia e trágico no suplício de Santiago}

Embora a palavra "trágico" se origine da palavra "tragédia", estas não são sinônimas. Segundo Aristóteles (1998, p.110) tragédia é "a imitação de acção de cáracter elevado, completa e de certa extensão, em linguagem ornamentada [...] e que suscitando o terror e a piedade tem por efeito a purificação dessas emoções". Nesse sentido, torna-se necessário apontar alguns elementos constitutivos da tragédia que aparecem no texto de García Márquez. São eles: o caráter, o tempo, a situação trágica e a dupla terror e piedade. $\mathrm{O}$ caráter diz respeito à qualidade das personagens. O perfil do herói trágico é de um homem viril, de grande reputação, que equilibra virtude e vícios e que está alheio à compreensão dos fatos. Santiago Nasar possuía certo prestígio devido à fortuna da família e não sabia que iria morrer. Sua virilidade aparece representada pelo falcão, ave que simboliza a extensão do falo. ${ }^{4}$

A situação trágica é marcada por uma ação que gera um infortúnio "a tragédia não é imitação de homens, mas de acções e de vida, de felicidade ou infelicidade" (ARISTÓTELES, 1998, p.111). O Texto de García Márquez apresenta uma situação trágica por excelência. Nasar

\footnotetext{
${ }^{4}$ Segundo Martin (2010, p. 496) esta caracterização de Nasar se deve ao fato de que Márquez viu em um Aeroporto na Argélia um príncipe árabe que carregava um falcão: "Havia de súbito aberto seus olhos para uma nova maneira de representar o conflito".
} 
cai em desgraça, passa da "dita para a desdita": "parecia feliz com o pai até que este morreu de repente, três anos antes, e continuou parecendo feliz com a mãe até a segunda feira da desgraça" (GARCÍA MÁRQUEZ, 2006, p. 15).

O terror e a piedade estão presentes no texto porque Santiago está em "situação intermediária": não é um homem ruim, também não é nenhum justiceiro, é como todo ser humano dotado de vícios e virtudes. Nos apiedamos de Nasar porque, possivelmente, ele não cometeu o crime: "a piedade tem lugar de respeito do que é infeliz sem o merecer" (ARISTÓTELES, 1998, p. 120). Nos aterrorizamos porque ainda que o tivesse cometido, não merecia ser punido com a morte.

O texto de Gabriel García Márquez se distancia da tragédia para assumir o aspecto trágico. Note-se que a sociedade em que Aristóteles vivia era extremamente injusta e por isso as noções de ética, de justiça e de igualdade estavam muito longe do povo. O autor da crônica adapta o herói trágico para uma pessoa que não é de origem nobre, mas se diferencia dos demais por ser visto como rico, o que resulta no retorno da visão trágica do mundo adaptada ao horizonte da América Latina. Nesse sentido, a crônica presta-se à aproximação tanto do estilo trágico quanto de uma sensibilidade trágica. Como aspecto dessa sensibilidade se pode observar a ideia de agonia como a origem do suplício de Santiago. Tal suplício está ligado à noção que Nietzsche (2012, p. 67) busca em Heráclito, de híbris, segundo a qual "a satisfação engendra o sacrilégio". Para Heráclito, o fim do mundo é algo periódico e repetido, no qual a criação de um novo mundo é produtora e produto de um impulso de destruição. Na visão desse grego, o mundo é sempre "um vir a ser e perecer" (NIETZSCHE, 2012 p. 68). Essa percepção pode aproximar o suplício repentino de Nasar com o fato de ter tido uma vida feliz sendo, a priori, uma improvável vítima de uma sina. "Pensava na crueldade do destino de Santiago Nasar, que lhe cobrara 20 anos de felicidades, não apenas com a morte, mas com o esquartejamento do corpo, sua dispersão e extermínio" (GARCÍA MÁRQUEZ, 2006, p. 115).

Outra questão apontada pelo trágico é uma eterna culpa carregada pelo humano que Nietzsche atribui à reparação de um "pecado original" de desligamento do humano em relação à natureza. Desse modo, é como se algo trágico estivesse à espreita, não como consequência de algo errado cometido no passado individual, mas como algo que carregamos como carga histórica coletiva. 
$\mathrm{Na}$ infância de Santiago, uma bala do revólver de Ibraim Nasar atravessara a casa e estraçalhara um santo do altar da Igreja. "Santiago, que então era muito criança, não esqueceu nunca a lição daquele contratempo" (GARCÍA MÁRQUEZ, 2006, p. 13). Mesmo que guardasse o revolver descarregado para evitar novos acidentes, Santiago acabaria sendo julgado pelo sacrilégio do pai. Como na tragédia edipiana, o herói trágico não é "culpável" pelo mal que o acomete de sua desgraça, mas a circularidade trágica na forma da vontade divina tende a cobrar a dívida da profanação do parente mais próximo para que a ordem se reestabeleça.

A imagem de Ibrahim Nasar não parece importante em uma primeira leitura da crônica, mas, ao longo do texto, sua semelhança com Santiago paira sobre a narrativa, associada à lida com falcões amestrados, representativa do legado de dominação masculina. Pode-se inferir que essa presença tangencial somada a símbolos de genealogia, como as árvores com que Santiago sonha, sejam indicativos de que sua sina é também uma dívida hereditária.

Outro aspecto trágico importante é a forma como as pessoas, que tiveram envolvimento com o crime, dão opiniões sobre a situação. Não acreditavam que Santiago tivesse cometido o crime, mas também não compreendem porque Ângela Vicário acusou-o com tanta veemência.

Assim, como o narrador/personagem, as demais pessoas organizam os fatos de forma contraditória, mas convergem na opinião de que, mesmo que a acusação fosse infundada, ninguém poderia fazer nada para impedir, porque ao sentenciar Santiago, era como se os irmãos já tivessem inscrito a morte dele na realidade da manhã que se iniciava na cidade. "A maioria dos que puderam fazer alguma coisa para impedir o crime e, apesar de tudo, não o fizeram, consolou-se com invocar o preconceito de que as questões de honra são lugares sagrados aos quais só os donos do drama têm acesso" (GARCÍA MÁRQUEZ, 2006, p. 144). Assim, Santiago iria morrer, querendo o povoado ou não e, como herói trágico, precipita-se para sua morte: sai de casa desarmado e pela porta que não costumava utilizar, entra na casa de Flora Miguel quando deveria ir para a sua e sai da casa de Flora quando deveria ter ficado lá para evitar o encontro com os Vicário até que a questão fosse esclarecida.

Os galos do amanhecer nos surpreendiam tentando ordenar as numerosas causalidades encadeadas que tornaram possível o absurdo, e era evidente que não o fazíamos por um desejo de esclarecer mistérios, mas porque nenhum de nós podia continuar 
vivendo sem saber com precisão qual era o espaço e a missão que a fatalidade lhe reservava (GARCÍA MÁRQUEZ, 2006, p. 143).

Algumas pessoas do povoado argumentaram que tiveram "visões" da figura de Santiago já morto e da imutabilidade da imagem que tinha sido desenhada pelos irmãos naquele povoado. Mesmo consolando-se por essa imutabilidade, uma fala do narrador indica que o povoado também se culpava pela situação trágica. Essa passagem é descrita quando o narrador comenta que a comunidade de árabes parentes de Santiago era pacífica e não efetuou sobre os Vicário qualquer retaliação: "Assim não era concebível que fossem alertar de repente seu espírito pastoral para vingar uma morte cujos culpados podíamos ser todos" (GARCÍA MÁRQUEZ, 2006, p. 120. Grifo nosso).

Aspecto essencial da sensibilidade trágica está na incorporação da noção de fatum à narrativa em torno da ação ou da inação dos personagens da crônica, isto é, do estabelecimento "de um destino previamente escrito que dirige sus actos y les impede ser duenos del mismo" (BENAVIDES, 2014, p. 334). Segundo Benavides (2014), a literatura de García Márquez tem como característica o desencadeamento de fatalidades, nas quais o autor demonstra reconhecer "en América Latina la presencia de un destino común sudamericano del que no se puede escapar” (BENAVIDES, 2014, p. 348). Para a autora tanto Cem anos de solidão quanto Crônica de uma morte anunciada são obras construídas "sobre o fatalismo" e questionam o ideal civilizatório evolucionista europeu. O fatum seria a violência desmedida, cometida contra os povos da América Latina durante séculos, e que ainda perpetua formas de exploração reconfiguradas mesmo depois da independência, as quais constituem parte da colonialidade. Desse modo, a incorporação do fatum e de outros aspectos da tragédia por García Márquez vai além de um processo estético literário e faz parte de um processo ideológico de crítica à reprodução das desigualdades e explorações comuns a todo o subcontinente e da tentativa de uma nova reescrita da história que desorganize as relações hierárquicas legitimadas nas narrativas dominantes.

\section{Considerações finais}

Algo fundamental da literatura de Gabriel Garcia Márquez é a forma como tece críticas a preceitos tradicionais da sociedade que descreve, utilizando a simbologia como estratégia. Em um trecho que 
fala sobre os irmãos Vicário, reconstrói a personalidade dos mesmos de tal forma que gera menos julgamento do que consternação: "Devia saber que a natureza humilde dos gêmeos não era capaz de resistir ao escárnio" (GARCÍA MÁRQUEZ, 2006, p. 149). Associados à figura do porco, signo da ignorância, os gêmeos são descritos como pessoas simples e não violentas, mas as regras sociais que lhes rodeavam não permitiam a vacilação diante da injúria. Sobre Bayardo San Román, a narrativa também conota que poderia ter evitado a tragédia se aceitasse a condição de Ângela. Descrito como simpático e de boa índole, também não demonstra capacidade de fugir do peso das tradições "sob suas vaidades mundanas, era tão dominado como qualquer outro por seus preconceitos de origem" (GARCÍA MÁRQUEZ, 2006 p. 149). Ao descrever o proceder dessas personagens, García Márquez chama atenção sobre a questão de como o controle sobre a sexualidade da mulher é o gerador do mal-estar que culmina com a morte, mas, além disso, aponta como o conservadorismo e as relações de dominação são produtores do sentido trágico que a situação descrita toma. Tanto na tragédia real ocorrida na Sucre dos anos 1950, quanto na crônica adaptada pelo autor, a negociação entre a violência concreta e o bizarro, converge em uma alegria trágica, um misto de consternação pelo sacrilégio de um jovem belo e feliz, e um alívio pela percepção da impermanência das coisas, entre elas, as noções de honra.

Essa alegria trágica pode estar representada na figura do juiz que analisa o processo-crime de mais de 500 páginas. Quando o personagem/ narrador volta ao povoado para rever as folhas, descobre que o juiz era apaixonado por literatura, apreciava Nietzsche e escreveu notas nos cantos das folhas do sumário que pareciam escritas com sangue. Sentiase contrariado pela forma como sua profissão e sua paixão se cruzavam naquele processo que descrevia a agência do acaso e a brutalidade da morte de forma tão detalhada, e o saboreava. "Nunca achou legítimo que a vida se servisse de tantos acasos proibidos à literatura para que se realizasse, sem percalços, uma morte tão anunciada" (GARCÍA MÁRQUEZ, 2006, p. 147).

Contrariando a imagem fixa da história, a literatura de García Márquez oferece um cenário "matizado" em que os limites entre fato e imaginário não são dados e, portanto, oferecem "uma versão", escapando do determinismo "da verdade" e permitindo a insuficiência da explicação. Ao fazer isto o autor deixa espaço para questionar-se sobre a dúvida que 
redunda em uma sensibilidade trágica: até que ponto a força humana é capaz de evitar que algo anunciado se cumpra? A impertinência das coisas, ambiguidade dos personagens e fatos e os emaranhados de causalidades que levaram ao acontecimento bizarro da morte anunciada talvez explique porque aparecem mais referências jornalísticas à pequena narrativa da Crônica de uma morte anunciada do que à epopeia de Cem anos de solidão.

\section{Referências}

ALMEIDA, Lélia. Iracema. In: BERND, Zilá (org.). Dicionário de figuras e mitos literários das Américas. Porto Alegre: Tomo Editorial/ Editora da Universidade, 2007.

ARISTÓTELES. Poética. Tradução e comentários de Eudoro de Souza. Brasília: Imprensa Nacional/Casa da Moeda, 1998.

BENAVIDES, Ana Cristina. La soledad de Macondo o la salvación por la memoria. Bogotá: Siglo del Hombre Editores, 2014.

BHABHA, Homi K. O Local da Cultura. Belo Horizonte: Editora UFMG, 2013.

CASTRO-GÓMEZ, Santiago. Ciências sociais, violência epistêmica e o problema da "invenção do outro". In: LANDER, Edgardo (org.). A colonialidade do saber: eurocentrismo e ciências sociais. Perspectivas latino-americanas. Buenos Aires: CLACSO, 2005a. (Colección Sur Sur) Disponível em: https://edisciplinas.usp.br/pluginfile.php/2591382/mod resource/content/1/colonialidade_do_saber_eurocentrismo_ciencias_ sociais.pdf. Acesso em: 28 fev. 2019.

CASTRO-GÓMEZ, Santiago. La poscolonialidad explicada a los niños. Popayán: Universidad del Cauca, 2005b.

GADEA, Carlos. A “Questão Pós” e a crítica pós-moderna. In: GADEA, Carlos; BARROS, Eduardo Portanova (org.). A "Questão Pós” nas Ciências Sociais: Crítica, estética, política e cultura. Curitiba: Appris, 2013. p.11-34.

GARCÍA MÁRQUEZ, Gabriel. Crônica de uma morte anunciada. Tradução de Remy Gorga, filho. 34. Ed. Rio de Janeiro: Record, 2006. 
HERSCOVITZ, Heloiza Golbspan. O Jornalismo Mágico de Gabriel García Márquez. Estudos em Jornalismo e Mídia, Florianópolis, v. 1, n. 2, p. 174-194, 2 ${ }^{\circ}$ Sem. 2004.

LYOTARD, Jean François. A condição pós-moderna. Rio de Janeiro: José. Olympio, 2004.

MARTIN, Gerald. Gabriel García Márquez: uma vida. Rio de Janeiro: Ediouro, 2010.

NIETZSCHE, Friedrich. A Filosofia na era trágica dos gregos. Porto Alegre: L\&PM Pocket, 2012.

RODRIGUES, Selma. Macondoamérica: a paródia no romance de Gabriel García-Márquez. Rio de Janeiro: Leviatã Publicações, 1993.

SAID, Edward W. Orientalismo: O Oriente como invenção do Ocidente. São Paulo: Companhia das Letras, 2007.

SPIVAK, Gayatri. Pode o subalterno falar? Belo Horizonte: Editora UFMG, 2010.

TORO, Alfonso de. Historiografía como construcción translatológica y transversal en la novella latinoamericana y española contemporánea (A. Roa Bastos, C. Fuentes, M. Vargas Llosa y A. Gala). In: TORO, Alfonso de; CEBALLOS, René (ed.). Expressiones liminales em la narrativa latino-americana del siglo $X X$ : Estratégias postmodernas y postcoloniales. Hildsheim, Zürich, New York: Verlag Klaus Dieter, Vervuert, 2007. (TKKL/TCCL, v. 38).

TORO, Alfonso de. Los fundamentos del pensamiento occidental del siglo XX: La 'postmodernidad' y la 'postcolonialidad'. In: GADEA, Carlos; BARROS, Eduardo Portanova (org.). A "Questão Pós” nas Ciências Sociais: crítica, estética, política e cultura. Curitiba: Appris, 2013.

TORO, Alfonso de; CEBALLOS, René. Introdução. In: TORO, Alfonso de; CEBALLOS, René (ed.). Expressiones liminales en la narrativa latino-americana del siglo $X X$ : Estrategias postmodernas y postcoloniales. Hildsheim, Zürich, New York: Verlag Klaus-Dieter, Vervuert, 2007. (TKKL/TCCL, v. 38).

Recebido em: 28 de junho de 2018. Aprovado em: 25 de janeiro de 2019. 